\title{
Quality Index Method (QIM) to Assess the Freshness and Shelf Life of Fish
}

\author{
Daniella Cristina Bernardi ${ }^{*}$, Eliane Teixeira Mársico and Mônica Queiroz de Freitas \\ Departamento de Tecnologia dos Alimentos; Faculdade Veterinária; Universidade Federal Fluminense; Rua Vital \\ Brazil Filho, 64; 24230340 - Niterói - RJ - Brasil
}

\begin{abstract}
The aim of this work was to develop a sensory method as the objective measure of quality of the fishes at all the key stages of fishery chain, from catch to consumer. The Quality Index Method (QIM) is based on a structured scaling for quality measurements and provides accurate and precise information concerning the freshness and a prediction of the remaining shelf-life for specie-specific fishes. The method is discussed and some future outlooks and need are pointed in order to stimulate the implementation of QIM in the relevant parts of the fishery chain giving unique information of the quality.
\end{abstract}

Key words: sensory analysis; fish quality; QIM, shelf life

\section{INTRODUCTION}

Consumers demand for high-quality, safe, and healthy foods is increasing on a global basis (Sen 2005). Consumer studies appear to indicate that quality is still the key buying cue for fish purchases (Alasalvar et al. 2011). Besides, in order to secure the food safety, it is important to keep the quality of fishes at a high level in each link of the whole complex chain from catch to consumer (Hyldig and Nielsen 2004). Fresh fish is a highly perishable product. The supplies of fishes are unstable and fresh fish can be stored only for a short time. For commercialization, it is essential to estimate accurately its freshness, one of the most important aspects of fish and fish products (Olafsdóttir 1997; Huidobro et al. 2001). Thus, the need for rapid analytical techniques to measure the food quality and freshness is greater than ever. Many methods have been tested, but sensory evaluation is still considered as the most effective technique to assess fish freshness and quality deterioration (Martinsdóttir 2002; Alasalvar et al. 2011). Often fish is sold and priced on freshness criteria. The fishes are brought on shore at designated landing sites where it is graded by fish inspector into different price groups based on the freshness using sensory analysis (Chebet 2010). Therefore, researchers have been working to improve the sensory methods (Huidobro et al. 2001).

The European fisheries research institutes, in close cooperation between the seafood industry, developed a new tool, by which sensory assessment is performed in a systematic and safe way with an objective quality assessment method, called the Quality Index Method (QIM) (Martinsdóttir et al. 2001). Based on a structured scaling method, the QIM is suggested as a practical and objective tool for evaluating the fresh fish in production management in official seafood inspection as well as other parts of the chain (Hyldig and Green-Petersen 2004). Besides the

*Author for correspondence: daniellabernardi@hotmail.com 
advantages assigned to all the sensory analysis, such as non-destructive, quick and cheap way of assessing the freshness changes, QIM takes into account specific aspects of each species, or product, assessing the quality and freshness of the fish by sensory analysis of a set of attributes considered relevant and it allows estimating the remaining shelf-life time of a lot (Huidobro et al. 2001; Esteves and Anibal 2007). It was developed initially for whole fishes stored in ice but currently it is also applied, among other products, to frozen fishes and fillets (Nunes et al. 2007). Actually, QIMs are available for a large range of fish and crustacean species, both wild and farmed (Nielsen 2005). Most of the scoring systems are based upon the changes taking places during the storage in melting ice (Martinsdóttir 2002).

This method had been expected to become the leading reference method for the assessment of fresh fish within the European community (Hyldig and Green-Petersen 2004). However, more studies are needed to evaluate the applicability of QIM for the handling, storage and processing of the fishes under different conditions. A further interesting initiative is the development of software for QIM using a convenient hand-held terminal that allows data to be electronically imputed during the sensory assessment (Howgate 2009).

This study aimed to present information about QIM, an objective tool to evaluate freshness that lately has received great attention from the industry, marketing and inspection sector, mainly in Europe, in order to stimulate the implementation of QIM in the relevant parts of the fishery chain, and so, facilitating the fish trade, improving the quality assurance and ensuring the traceability of quality information of fish for the consumers.

\section{IMPORTANCE OF EVALUATION OF FISH \\ SENSORY}

Sensory evaluation is one of the most important methods for assessing freshness and quality in the fishing sector and in fish-inspection services. Sensory methods performed in a proper way are a rapid and accurate tool providing unique information about the food (Hyldig et al. 2007). They can be very fast, reliable, non-destructive on raw fish and no expensive instruments are needed. They give direct measurement of the perceived attributes and provide information assisting in better understanding of consumer responses. However the panelists need training and retraining under the supervision of experienced panel leaders using fish samples of known freshness stage (Martinsdóttir 2002).

Sensory evaluation can be practiced at different levels in fish processing such as after landing, arriving at the fish plant (whole), at the reception, or processing halls of fish factories; evaluation of raw/cold and cooked fillets at the reception, or processing halls of fish factories, or at auction sites, very common in Europe (Martinsdóttir 2002; Hyldig et al. 2010). Traditionally, sensory methods have been seen as a subjective assessment of the quality. However, they can be turned into an objective tool (Hyldig et al. 2007). Progress has been made in sensory evaluation during the last years mainly because of the use of computers and data analysis. The work of collecting and analyzing data is not very time-consuming and the information on the results can be used and correlated with other information on the products as well. No single instrumental method has so far been foreseen to replace the sensory methods (Martinsdóttir et al. 2003).

\section{THE QIM-METHOD}

European fisheries research institutes have developed such a tool, by which sensory assessment is performed in a systematic way with an objective quality assessment method (Hyldig et al. 2007). The Quality Index Method (QIM), as it has come to be known, is a systematic, objective guideline that simplifies the quality-assessment process. It originated from Tasmania, during the late 1970s and early 1980s, by the Tasmanian Food Research Unit (TFRU) of the Commonwealth Scientific and Industrial Research Organization (CSIRO), but most QIM schemes have been developed in Europe, where the method is widely applied (Nielsen 2005).

QIM was born out of necessity, since no satisfactory method existed that could be used on a variety of species, did not require extensive training, was robust, easy to understand, and capable of integrating the effects of time and temperature (Hyldig et al. 2007). The QIM scheme addresses some of the inherent limitations contained in the EU grading scheme like not taking into account the difference between the 
species (Hyldig et al. 2010). It does not measure the quality itself, or freshness but rather the degree, or rate of change in important criteria used to describe these qualities (Green 2011).

QIM uses a practical rating system in which the fish is inspected and demerit points are recorded (Sen 2005). This approach was derived from the understanding that during the storage of fish, changes occur that are readily detectable and often measurable. This is also in keeping with the fact that the vast majority of chemical, biochemical, and microbiological tests on fish products start from either zero, or a low value and increase with both temperature and period of storage (Hyldig et al. 2010). The use of a scaling method establishes robust data, reflecting the different quality levels of the fish in a simple and well-documented way. The QIM is based on significant sensory quality parameters using the well-defined characteristics changes of outer appearance attributes for raw fish and a score system from 0 to 3 demerit points (Hyldig and Green-Petersen 2004; Martinsdóttir 2002). The technique (described in Fig. 1) is based on selecting a number of quality attributes characteristic for a particular species and allocating the scores to each attribute depending on the state of freshness, or quality of the selected food item (Sveinsdóttir et al. 2003).

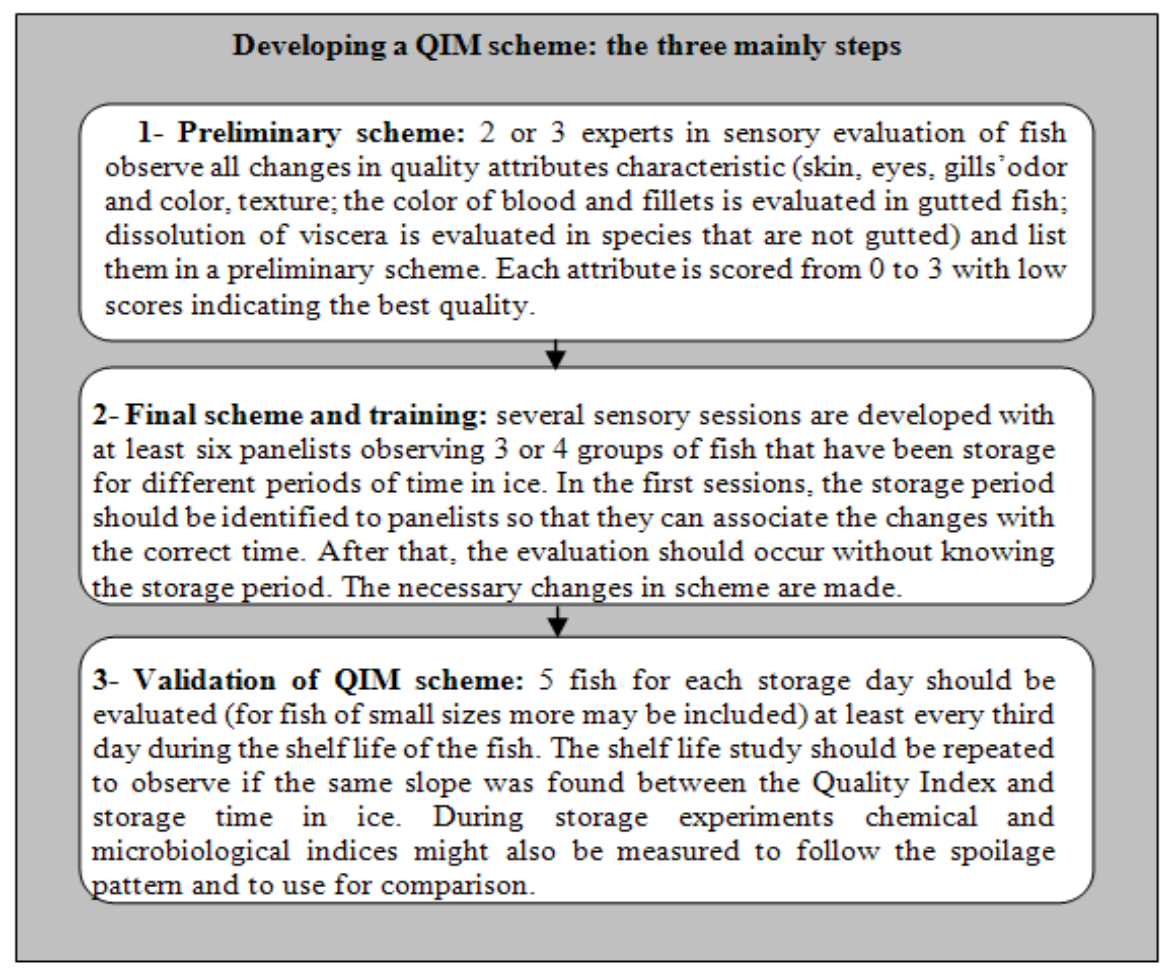

Figure 1 - A general chart of the process necessary to develop a QIM scheme (Matinsdóttir 2002).

The attributes to be evaluated when applying, or developing the QIM schemes are skin, eyes, gills and texture. The odor of gills, and for some species, the odor and mucus of the skin are also evaluated. The color of the blood and fillets (or the cut surface at the flaps) is evaluated in the gutted fish. For some fish species that are not gutted, such as redfish, dissolution of viscera is evaluated as well (Martinsdóttir 2002).
The selection of parameters for the QIM is determined as a combination of the best descriptors for the spoiling fish, which also fulfill the aim of giving a linear correlation to the shelf life (Hyldig and Nielsen 2004). Each attribute is scored from 0 to 3 by novice, or experienced assessors with low scores indicating the best quality. The scoring allotted to each criterion is such that no single criterion could dominate and that the score values are easy to judge (Hyldig et 
al. 2010). The sum of all the attributes is called demerit points, or QIM index points. This value increases linearly with the storage time on ice of a given fish.

Using the QIM system, the linear relationship between the quality index (QI) and the storage time on the ice makes it easy to calculate the remaining shelf-life of fish (Hyldig et al. 2007).

Since all the fishes have their own distinctive spoilage patterns and sensory attributes, QIM schemes are developed for the individual species (Green 2011). All the schemes have been developed using the seafood that have been produced according to good manufacturing practice (i.e., held in melting ice since the capture). This makes it possible to identify the seafood that shows atypical characteristics, or which appears to have spoiled more quickly than expected, which can be linked to poor practices such as high temperature spoilage, inadequate icing, etc (Archer 2010).

Although schemes can be readily expressed and constructed in different languages, a numerical value as an output is universal and can be understood by all. The score can be used to judge the handling and storage procedures, efficiencies of personnel, and duration of transport, and it is particularly useful in troubleshooting (Hyldig et al. 2007). The main advantages in using QIM are that it is non-destructive and it takes into account the differences between the species (Green-Petersen 2010). According to Nielsen (2005), QIMs are easier to use than some sensory methods and do not require any equipment other than the human senses. All the quality descriptors are well defined, and most of the schemes include thorough instructions with illustrations. As a result, limited training is needed to achieve accurate results. Martinsdóttir (2002) reported that as the Quality Index increased linearly with the storage time on the ice, the information was well suited to use in the production management. QIM is well suited to teach the inexperienced people to evaluate the fish, train the panelists and monitor the performance of the panelists since it is an objective method and includes instructions and easily understood illustrational material.

The QIM approach can be used by all links in the seafood supply chain - farmers, distributors, buyers, and consumers - assuring more uniform evaluation and fewer misunderstandings. With the QIM, it is possible to give more detailed information of the sensory quality, and thereby, fulfill the primary producer's demand. Using QIM scores, farmers can sort crops into quality categories and market them to the most appropriate customer segments. The processors can use the QIMs to estimate the shelf-life and plan the production more efficiently (Nielsen 2005). The QIM can also measure the influences of transport/storage on the sensory quality and the remaining shelf-life when the fish/fish product is stored on the ice (Hyldig and Green-Petersen 2004). For the electronic auctions, where buyers purchase the fishes unseen, QIMs have an obvious advantage over other sensory methods. The quality indexes can also play an important role in the traceability, because such data can be applied through the entire chain to check the accuracy (Nielsen 2005).

Hyldig et al. (2007) found that the result obtained in the scheme could be used as an index of what the material might be like for an appropriate end use. This may be a judgment of its ability to withstand a process, or its selection for a particular grade of the product, or it may foreshadow what the product is anticipated to be like when it is cooked and eaten by the consumer (Hyldig et al. 2007).

\section{QIM DATA ANALYSIS}

Data analysis is an important part of the development of QIM. The results from the shelflife studies should be fitted into a linear relationship and studied to check the linearity of the Quality Index. The changes of all the attributes during the storage should be studied and the weight of scores might be changed to obtain a QI with higher correlation to storage time (Martinsdóttir 2002). Data obtained from the MIQ scheme must be analyzed by the linear regression to fit the time-dependent regression. To determine the precision (standard error of estimate) of the prediction by the newly developed QIM scheme, QI results must be submitted to partial least-square regression (PLS). The evaluation of importance for each sensory parameter is determined by the principal component analysis (PCA) on a matrix with the objects (samples) and variables. Before the PCA, the variables are standardized to mean of zero and variance of one (Bogdanovic et al. 2012). The Pearson correlation analysis is used to determine the relationships between the time of iced storage versus QI (Sant' ana et al. 2011). 


\section{QIM SCHEMES}

QIM advantages have led to the development of specific schemes for different species in several countries. QIM schemes are available for a range of wild and farmed fishes and crustaceans, particularly in Europe. Table 1 summarizes the schemes built for 49 different fishes species, between 2000 and 2011 available in the scientific literature, with the respective storage conditions, Quality Index (QI) range and estimated shelf life. Besides these species, there are seven more compiled by Barbosa and Vaz-Pires (2004) built between 1992 and 1999.

Although there are 49 fish species listed in Table 1, 56 specifically designed QIM schemes are presented for different products, sometimes of the same species. In the case of shrimps for example, there are two schemes for each species, Macrobrachium amazonicum (Portela 2009), Pandalus borealis (Martinsdóttir et al. 2001) and Litopenaeus vannamei (Oliveira et al. 2009), one for raw and whole, and other for the headless and/or peeled crustacean. It's interesting to notice that for all these schemes the parameters odour and colour were evaluated.

Other species that present two developed QIM schemes are cod (Gadus morhua), cuttlefish (Sepia officinalis), and gilthead seabream (Sparus aurata). For cod, one scheme was developed to evaluate the raw and gutted fishes (Martinsdóttir et al. 2001) and one for the raw cod fillets with skin (Bonilla et al. 2007), the unique scheme for fillets developed between 2000 and 2011 available in scientific literature. The number of parameters included in the QIM scheme developed for fresh cod fillets (8) were lower than that developed for the raw gutted fishes (10). The same was observed for the shelf-life (14 days for fillets, 15 for fish). Vaz-Pires and Seixas (2006) developed the first QIM scheme for the cuttlefish using raw samples, whole and washed with tap water before the storage on the ice. Sykes et al. (2009), reporting this as not a common procedure in the fishing industry, developed a QIM scheme for unwashed cuttlefish. Different parameters between the schemes were used and head and mantle cavity were included as attributes, with three and four parameters to evaluate each one. This allowed a more accurate analysis of spoilage in
S. officinalis. As show- in Table 1, lower QIM scores and a higher shelf life for the one washed before storage were obtained.

QIMs schemes were proposed for the raw and gutted gilthead seabream (Sparus aurata) stored on the ice (Huidobro et al. 2000) and for gilthead seabream packed under MAP (Campus et al. 2011). Comparing both, the QIM scheme developed by Campus et al. (2011) has a higher number of parameters (13 instead of 8 ) and higher total demerit points (25 instead of 15). These authors included in the scheme some useful parameters to discriminate early fish freshness modifications, namely rigor state, pupil and muscle color. Moreover belly firmness, which was found always to sunken in the latter stages of storage in MAP, and the gills mucus, which was related to microbial proliferation and degradation of gills tissues, were also included in the parameter list. The maximum storage time was 15 and 13 days to gilthead seabream storage on the ice and at $4{ }^{\circ} \mathrm{C}$ for MAP $60 \% \mathrm{CO}_{2}$ and $40 \% \mathrm{~N}_{2}$, respectively (Campus et al. 2011).

Differing from gilthead seabream, processed herring (Clupea harengus) named Maatjes herring, a lightly salted and fermented ready-to-eat fish product, very popular in The Netherlands, had developed just one QIM scheme for both the stored in air and under modified atmosphere packaging (MAP) (Lyhs and Schelvis-Smit 2005). According to the authors, for the first time, the taste was included in a QIM scheme. Since natural variations and processing of the maatjes herring limited the use of the QIM scheme, they proposed that the product-specific differences and storage conditions must be specified in more detail. Most of the scoring systems shown in Table 1, for example, 52 from a total of 55 proposed schemes, representing 94,54\%, are based upon the changes taken place during the storage in melting ice. However, it is also possible to develop the QIM schemes that can be used, for example, to evaluate the freshness in the thawed fish such as for Maatjes herring (Clupea harengus) (Lyhs and Schelvis-Smit 2005), frozen fish for hake (Merluccius capensis and M. paradoxus) (Herrero et al. 2003) and Refrigerated Sea Water (RSW) storage for Australian sardines (Sardinops sagax) (Musgrove et al. 2007) 
Table 1 - QIM schemes built for 49 different fish species, between 2000 and 2011 available in the scientific literature, with the respective storage conditions, Quality Index (QI) range and estimated shelf life.

\begin{tabular}{|c|c|c|c|c|c|}
\hline Species & Product & Storage conditions & QI & $\begin{array}{l}\text { Estimated } \\
\text { shelf life }\end{array}$ & Reference \\
\hline \multirow{2}{*}{$\begin{array}{l}\text { Amazon River prawn } \\
\text { (Macrobrachium amazonicum) }\end{array}$} & Raw, whole, farmed & Chilled in crushed ice & $0-10$ & $10 \mathrm{~d}$ & \multirow[b]{2}{*}{ Portela 2009} \\
\hline & $\begin{array}{l}\text { Raw, farmed, headless } \\
\text { and peeled }\end{array}$ & Chilled in crushed ice & $0-8$ & $20 \mathrm{~d}$ & \\
\hline Arctic Char (Salvelinus alpinus) & Raw, whole, farmed & Chilled in ice $\left(0^{\circ} \mathrm{C}\right)$ & $0-24$ & $17 \mathrm{~d}$ & Cyprian et al. 2008 \\
\hline $\begin{array}{l}\text { Atlantic halibut (Hippoglossus } \\
\text { hippoglossus L.) }\end{array}$ & Raw, gutted, farmed & $\begin{array}{l}\text { Wrapped in plastic bags } \\
\text { and chilled in ice }\end{array}$ & $0-29$ & $22 \mathrm{~d}$ & $\begin{array}{l}\text { Guillerm-Regost } \\
\text { et al. } 2006\end{array}$ \\
\hline Atlantic Salmon (Salmo salar) & Raw, gutted, farmed & Chilled in slush ice $\left(0^{\circ} \mathrm{C}\right)$ & $0-24$ & $20 \mathrm{~d}$ & $\begin{array}{l}\text { Sveinsdóttir et al. } \\
2002 ; 2003\end{array}$ \\
\hline $\begin{array}{l}\text { Australian sardines } \\
\text { (Sardinops sagax) }\end{array}$ & Raw, whole & RSW storage & $0-22$ & $7-15 \mathrm{hs}$ & $\begin{array}{l}\text { Musgrove } \\
\text { et al. } 2007\end{array}$ \\
\hline $\begin{array}{l}\text { Bigmouth-anchovy } \\
\text { (Cetengraulis edentulus) }\end{array}$ & Raw, whole & Chilled in ice $\left(0 \pm 2{ }^{\circ} \mathrm{C}\right)$ & $0-23$ & $9 \mathrm{~d}$ & Silva 2010 \\
\hline $\begin{array}{l}\text { Black scabbardfish (Aphanopus } \\
\text { carbo) }\end{array}$ & Raw, whole & Chilled in ice & $0-19$ & $9 \mathrm{~d}$ & Nunes et al. 2007 \\
\hline $\begin{array}{l}\text { Blackspot seabream (Pagellus } \\
\text { bogaraveo) }\end{array}$ & Raw, whole & Chilled in crushed ice & $0-30$ & $12-13 \mathrm{~d}$ & Sant'ana et al. 2011 \\
\hline Bogue (Boops boops, L.) & Raw, whole, wild & $\begin{array}{l}\text { Chilled in ice } \\
\left(1 \pm 1{ }^{\circ} \mathrm{C}\right)\end{array}$ & $0-20$ & $12 \mathrm{~d}$ & $\begin{array}{l}\text { Bogdanovic } \\
\text { et al. } 2012\end{array}$ \\
\hline $\begin{array}{l}\text { Brazilian sardine (Sardinella } \\
\text { brasiliensis) }\end{array}$ & Raw, whole & $\begin{array}{l}\text { Chilled in ice } \\
\left(0 \pm 2{ }^{\circ} \mathrm{C}\right)\end{array}$ & $0-19$ & $10 \mathrm{~d}$ & Silva 2010 \\
\hline $\begin{array}{l}\text { Bream (Megalobrama } \\
\text { amblycephala) }\end{array}$ & Raw, gutted & $\begin{array}{l}\text { Packed in polyethylene } \\
\text { bags and stored at } 4 \pm \\
1^{\circ} \mathrm{C}\end{array}$ & $0-33$ & $12 \mathrm{~d}$ & Song et al. 2011 \\
\hline Brill (Rhombus laevis) & Raw, whole & Chilled in ice & $0-28$ & $14 \mathrm{~d}$ & $\begin{array}{l}\text { Marttisdóttir } \\
\text { et al. } 2001\end{array}$ \\
\hline $\begin{array}{l}\text { Broadtail shortfin squid } \\
\text { (Illex coindetii) }\end{array}$ & Raw, whole & $\begin{array}{l}\text { Chilled in crushed ice } \\
\left(2 \pm 2^{\circ} \mathrm{C}\right) \text {. }\end{array}$ & $0-16$ & $9 \mathrm{~d}$ & $\begin{array}{l}\text { Vaz-Pires and } \\
\text { Seixas } 2006\end{array}$ \\
\hline \multirow[b]{2}{*}{ Cod (Gadus morhua) } & Raw, gutted & Chilled in ice & $0-23$ & $15 \mathrm{~d}$ & $\begin{array}{l}\text { Marttisdóttir et al. } \\
2001\end{array}$ \\
\hline & Fillets & $\begin{array}{l}\text { Covered with low density } \\
\text { polypropylene and } \\
\text { chilled in ice }\left(0-1{ }^{\circ} \mathrm{C}\right)\end{array}$ & $0-18$ & $14 \mathrm{~d}$ & Bonilla et al. 2007 \\
\hline $\begin{array}{l}\text { Common octopus (Octopus } \\
\text { vulgaris) }\end{array}$ & Raw, whole & Chilled in ice & $0-16$ & $7 \mathrm{~d}$ & $\begin{array}{l}\text { Barbosa and } \\
\text { Vaz-Pires 2004 }\end{array}$ \\
\hline \multirow{2}{*}{ Cuttlefish (Sepia officinalis) } & Raw, whole, washed & $\begin{array}{l}\text { Chilled in crushed ice } \\
\left(2 \pm 2{ }^{\circ} \mathrm{C}\right) .\end{array}$ & $0-17$ & $10 \mathrm{~d}$ & $\begin{array}{l}\text { Vaz-Pires and } \\
\text { Seixas } 2006\end{array}$ \\
\hline & $\begin{array}{l}\text { Raw, whole, } \\
\text { unwashed }\end{array}$ & $\begin{array}{l}\text { Chilled in crushed ice } \\
\left(0^{\circ} \mathrm{C}\right) \text {. }\end{array}$ & $0-24$ & $8 \mathrm{~d}$ & Sykes et al. 2009 \\
\hline $\begin{array}{l}\text { Deep water shrimp (Pandalus } \\
\text { borealis) }\end{array}$ & Whole & Chilled in ice & $0-11$ & $6 \mathrm{~d}$ & $\begin{array}{l}\text { Marttisdóttir et al. } \\
2001\end{array}$ \\
\hline Eel (Anguilla anguilla) & Raw, gutted, farmed & Chilled in ice & $0-24$ & $12-14 \mathrm{~d}$ & Özogul et al. 2005 \\
\hline $\begin{array}{l}\text { European hake (Merluccius } \\
\text { merluccius ) }\end{array}$ & Raw, gutted & Chilled in ice & $0-19$ & $15 \mathrm{~d}$ & Nunes et al. 2007 \\
\hline $\begin{array}{l}\text { European seabass } \\
\text { (Dicentrarchus labrax) }\end{array}$ & Raw, gutted & Chilled in ice & $0-18$ & $22 \mathrm{~d}$ & Nunes et al. 2007 \\
\hline Flouder (Paralichthys patagoius) & Raw, whole & Chilled in ice & $0-32$ & $7 \mathrm{~d}$ & Massa et al. 2005 \\
\hline \multirow{2}{*}{ Fjord shrimp (Pandalus borealis) } & \multirow{2}{*}{$\begin{array}{l}\text { Raw, whole } \\
\text { Cooked, headless and } \\
\text { peeled }\end{array}$} & \multirow[b]{2}{*}{ Chilled in ice } & $0-11$ & $6 \mathrm{~d}$ & \multirow{2}{*}{$\begin{array}{l}\text { Marttisdóttir et al. } \\
2001\end{array}$} \\
\hline & & & $0-13$ & $6 \mathrm{~d}$ & \\
\hline \multirow{3}{*}{$\begin{array}{l}\text { Gilthead Seabream (Sparus } \\
\text { aurata) }\end{array}$} & \multirow{3}{*}{ Raw, gutted } & $\begin{array}{l}\text { Chilled in flake ice } \\
\left(2 \pm 1^{\circ} \mathrm{C}\right)\end{array}$ & $0-15$ & $15 \mathrm{~d}$ & \multirow{3}{*}{$\begin{array}{l}\text { Huidobro et al. } \\
2000 \\
\text { Alasalvar et al. } \\
2001 \\
\text { Campus et al. } \\
2011\end{array}$} \\
\hline & & Chilled in ice $\left(2 \pm 2^{\circ} \mathrm{C}\right)$ & $0-38$ & $17-18 \mathrm{~d}$ & \\
\hline & & $\begin{array}{l}\text { Chilled at } 2 \text { and } 4{ }^{\circ} \mathrm{C} \\
\text { MAP ** }\end{array}$ & $0-25$ & $13 \mathrm{~d}$ & \\
\hline
\end{tabular}


Cont. Table 1

\begin{tabular}{|c|c|c|c|c|c|}
\hline Species & Product & Storage conditions & QI & $\begin{array}{l}\text { Estimated } \\
\text { shelf life }\end{array}$ & Reference \\
\hline $\begin{array}{l}\text { Goldband goatfish(Upeneus } \\
\text { moluccensis) }\end{array}$ & Raw, gutted & Chilled in flake ice & $0-18$ & $8 \mathrm{~d}$ & Özyurt et al. 2009 \\
\hline $\begin{array}{l}\text { Haddock (Melanogrammus } \\
\text { aeglefius) }\end{array}$ & Raw, gutted & Chilled in ice & $0-23$ & $15 \mathrm{~d}$ & $\begin{array}{l}\text { Marttisdóttir et al. } \\
2001\end{array}$ \\
\hline $\begin{array}{l}\text { Hake (Merluccius capensis and } \\
\text { M. paradoxus) }\end{array}$ & Raw, gutted & Frozen at $-20^{\circ} \mathrm{C}$ & $0-17$ & $20 \mathrm{~m}$ & Herrero et al. 2003 \\
\hline Herring (Clupea harengus) & Raw, gutted & Chilled in ice & $0-20$ & $8 \mathrm{~d}$ & $\begin{array}{l}\text { Marttisdóttir et al. } \\
2001\end{array}$ \\
\hline $\begin{array}{l}\text { Horse Mackerel (Trachurus } \\
\text { trachurus) }\end{array}$ & Raw, gutted & Chilled in ice & $0-16$ & $7 \mathrm{~d}$ & Nunes et al. 2007 \\
\hline $\begin{array}{l}\text { Hybrid striped bass (Morone } \\
\text { saxalis } x \text { Morone chrysops) }\end{array}$ & Raw, whole, farmed & Chilled in ice & $0-14$ & $14 \mathrm{~d}$ & $\begin{array}{l}\text { Nielsen and } \\
\text { Green } 2007\end{array}$ \\
\hline Lobster (Panulirus Argus) & Pre-cooked, whole & $\begin{array}{l}\text { Chilled in ice pack at } \\
0-4^{\circ} \mathrm{C}\end{array}$ & $0-12$ & $10 \mathrm{~d}$ & Silva 2009 \\
\hline $\begin{array}{l}\text { Maatjes herring (Clupea } \\
\text { harengus) }\end{array}$ & $\begin{array}{l}\text { Raw, beheaded, } \\
\text { ungutted and brined }\end{array}$ & $\begin{array}{l}\text { Thawed and chilled at } \\
4{ }^{\circ} \mathrm{C} \text { unpacked } \\
\text { Thawed and chilled at } \\
4{ }^{\circ} \mathrm{C} \text { MAP } * *\end{array}$ & $0-25$ & $\begin{array}{l}1 \mathrm{~d} \\
4 \mathrm{~d}\end{array}$ & $\begin{array}{l}\text { Lyhs and Schelvis- } \\
\text { Smit } 2005\end{array}$ \\
\hline $\begin{array}{l}\text { Maroccan Sardine (Sardina } \\
\text { pilchardus) }\end{array}$ & Raw, whole & Chilled in crushed ice & $0-22$ & $4 \mathrm{~d}$ & $\begin{array}{l}\text { Triqui and } \\
\text { Bouchriti } 2003\end{array}$ \\
\hline $\begin{array}{l}\text { Meder's mangrove crab } \\
\text { (Neoepisesarma mederi) }\end{array}$ & Raw, whole & $\begin{array}{l}\text { Packed in polyethylene } \\
\text { zip bag and chilled in } \\
\text { flake ice }\left(0-2^{\circ} \mathrm{C}\right)\end{array}$ & $0-23$ & $6 \mathrm{~d}$ & $\begin{array}{l}\text { Noojuy and } \\
\text { Boonprab } 2008\end{array}$ \\
\hline $\begin{array}{l}\text { Mediterranean anchovies } \\
\text { (Engraulis encrasicholus) }\end{array}$ & Raw, whole & Chilled in ice & $0-23$ & $5 \mathrm{~d}$ & $\begin{array}{l}\text { Pons-Sachéz- } \\
\text { Cascado et al. } 2006\end{array}$ \\
\hline $\begin{array}{l}\text { Mediterranean Hake (Merluccius } \\
\text { merluccius var. mediterraneus) }\end{array}$ & Raw, gutted & $\begin{array}{l}\text { Chilled in flake ice } \\
\left(0^{\circ} \mathrm{C}\right)\end{array}$ & $0-19$ & $14 \mathrm{~d}$ & $\begin{array}{l}\text { Baixas-Nogueras } \\
\text { et al. } 2003\end{array}$ \\
\hline Plaice (Pleuroectes platessa) & Raw, whole & Chilled in ice & $0-24$ & $13 \mathrm{~d}$ & $\begin{array}{l}\text { Marttisdóttir et al. } \\
2001\end{array}$ \\
\hline Pollock (Pollachius virens) & Raw, gutted & Chilled in ice & $0-23$ & $18 \mathrm{~d}$ & $\begin{array}{l}\text { Marttisdóttir et al. } \\
2001\end{array}$ \\
\hline $\begin{array}{l}\text { Rainbow trout (Onchorhynchus } \\
\text { mykiss) }\end{array}$ & Raw, whole & Chilled in ice & $0-100$ & $14-16 \mathrm{~d}$ & $\begin{array}{l}\text { Wünnenburg and } \\
\text { Oehlenschäger } \\
2008\end{array}$ \\
\hline Red mullet (Mullus barbatus) & Raw, gutted & Chilled in flake ice & $0-18$ & $11 \mathrm{~d}$ & Özyurt et al. 2009 \\
\hline $\begin{array}{l}\text { Redfish (Sebastes } \\
\text { mentella/marinus) }\end{array}$ & Raw, whole & Chilled in ice & $0-23$ & $18 \mathrm{~d}$ & $\begin{array}{l}\text { Marttisdóttir et } \\
\text { al. } 2001\end{array}$ \\
\hline $\begin{array}{l}\text { Sea Bass (Dicentrarchus } \\
\text { labrax) }\end{array}$ & $\begin{array}{l}\text { Raw, whole, farmed } \\
\text { and wild }\end{array}$ & $\begin{array}{l}\text { Chilled in flake ice } \\
\left(2-4^{\circ} \mathrm{C}\right)\end{array}$ & $0-39$ & $16-18 \mathrm{~d}$ & $\begin{array}{l}\text { Alasalvar et al. } \\
2002\end{array}$ \\
\hline $\begin{array}{l}\text { Senegalese sole (Solea } \\
\text { senegalensis) }\end{array}$ & Raw, whole, farmed & Chilled in ice & $0-22$ & $15 \mathrm{~d}$ & $\begin{array}{l}\text { Gonçalves et al. } \\
2007\end{array}$ \\
\hline Shrimp (Litopenaeus vannamei) & $\begin{array}{l}\text { Raw, whole, farmed } \\
\text { Raw, headless, farmed }\end{array}$ & Chilled in ice & $\begin{array}{l}0-10 \\
0-8 \\
\end{array}$ & $\begin{array}{l}12 \mathrm{~d} \\
14 \mathrm{~d}\end{array}$ & $\begin{array}{l}\text { Oliveira et al. } \\
2009\end{array}$ \\
\hline $\begin{array}{l}\text { Silver scabbardfish (Lepidopus } \\
\text { caudatus) }\end{array}$ & Raw, whole & Chilled in ice & $0-17$ & $11 \mathrm{~d}$ & $\begin{array}{l}\text { Nunes et al. } \\
2007\end{array}$ \\
\hline Sole (Solea vulgaris) & Raw, whole & Chilled in ice & $0-28$ & $15 \mathrm{~d}$ & $\begin{array}{l}\text { Marttisdóttir et } \\
\text { al. } 2001\end{array}$ \\
\hline Tilapia (Oreochromis niloticus) & Raw, gutted, farmed & $\begin{array}{l}\text { Chilled in ice }\left(0,3^{\circ} \mathrm{C} \pm\right. \\
0,35)\end{array}$ & $0-19$ & $15 \mathrm{~d}$ & Rodrigues 2008 \\
\hline $\begin{array}{l}\text { Tub gurnard (Chelidonichthys } \\
\text { lucernus) }\end{array}$ & Raw, whole & Chilled in ice & $0-22$ & $18-19 \mathrm{~d}$ & Bekaert 2006 \\
\hline Turbot (Scophtalmus maximus) & Raw, whole & Chilled in ice & $0-28$ & $15 \mathrm{~d}$ & $\begin{array}{l}\text { Marttisdóttir et } \\
\text { al. } 2001\end{array}$ \\
\hline $\begin{array}{l}\text { Whitemouth croaker } \\
\text { (Micropogonias furnieri) }\end{array}$ & Raw, gutted & Chilled in ice & $0-22$ & $14 \mathrm{~d}$ & $\begin{array}{l}\text { Teixeira et al. } \\
2009\end{array}$ \\
\hline
\end{tabular}




\section{DIFFERENT PROCEDURES PROCESSING TECHNOLOGY}

AND

The usefulness of QIM is to determine how different ways of handling, processing, and storage conditions affect the fish shelf life such as under MAP and temperature abuse during the storage (Martinsdóttir et al. 2003). The QI is not only species related, but also related to the processing technology adopted, so different schemes should take into account products' specific differences (Lyhs and Schelvis-Smit 2005). Huidobro et al. (2001) investigated the effect of washing gilthead seabream (Sparus aurata) with tap water during the storage on the results of sensory evaluation by QIM. The results indicated that washing reduced the demerit points assigned when the raw gilthead seabream was evaluated with the QIM. The maximum allowable score for this species was not reached in the washed fishes even when the storage period set on the basis of both sensory and microbiological considerations was exceeded. Washing also delayed the limit of microbiological acceptability.

The QIM evaluations were also performed on whole herring (Clupea harengus L.) by Nielsen and Hyldig (2004), from ten seasonally and geographically distributed cruises and related to handling procedures. A significant difference was found between how fast the changes occur (i.e., the slope values) in the odor of whole herring (Clupea harengus L.), the appearance of eyes and the odor of gills in ice and tank-stored herring (Clupea harengus L.). Tank stored herring (Clupea harengus $L$.) obtained higher demerit points than the ice stored herring (Clupea harengus L.) for all the descriptors, except blood on gill cover. The QIM evaluations performed on herring (Clupea harengus L.) from ten cruises over a nine-month period showed the onboard storage methods to have profound influence on the quality.

Nielsen and Green (2007) developed a QIM for farmed hybrid striped bass (Morone saxalis $x$ Morone chrysops). Two farms participated in the QIM development with different fishes: one farmer harvested directly from the pond; the other included a purging step in which residual feed was removed from the stomachs of the fishes by placing the fish in a tank with clear fresh water. The differences in the quality due to these procedures could be quantified with the QIM. It was found that hybrids harvested directly from the pond more frequently had muddy, or earthy odors than the purged fish. It was inferred that fish farmers could use such data to get a better picture of how different practices influenced the quality of their products and adjust their procedures accordingly. Using the QIM scores, they can sort crops more precisely into quality categories and market them to the most appropriate customer segments.

Besides handle, different storage condition can also present different effects. Cyprian et al. (2008) reported that during the fish storage, it is not uncommon that a batch is temporarily exposed to higher temperature. Based on that, changes during the storage were observed in two groups of farmed arctic char (Salvelinus alpinus) using the QIM method. One group was stored on ice up to 18 days and the other was stored at $18^{\circ} \mathrm{C}$ for $24 \mathrm{~h}$ (temperature increased from 3 to $12^{\circ} \mathrm{C}$ ), then iced and stored up to 18 days. This increase in the temperature for a short time led to two days shorter storage life of arctic char (Salvelinus alpinus) stored on ice (15 days for the temperature-abused fishes and 17 days for the other group). The spoilage in abused fishes was predominantly bacterial, while in well-handled fishes, it occurred as a result of both bacterial and chemical activities.

Campus et al. (2011) evaluated the effect of MAP packed farmed gilthead seabream (Sparus aurata) on QIM scores at low $\left(2^{\circ} \mathrm{C}\right)$ and abused temperatures $\left(8^{\circ} \mathrm{C}\right)$. The storage at $2^{\circ} \mathrm{C}$ did not substantially improved the sensory parameters scores when compared to storage at $4^{\circ} \mathrm{C}$, while the storage under temperature abuse $\left(8^{\circ} \mathrm{C}\right)$ accelerated drastically the rate of increase of QI scores and reduced the maximum storage time $\left(\right.$ at $\left.4^{\circ} \mathrm{C}\right)$ from 13 days to 6 days. Bogdanovic et al. (2012) developed a QIM scheme for raw bogue (Boops boops) and evaluated it in a shelf-life study, using the samples from the wild fishes aggregations at fish farms (BF) and from the area not influenced by the fish farms (BW). Between the nine parameters defined as distinguishable, blood on neck was added as new character showing clear evolution during the storage and expressed as percentage (0, 1 to 50 and 51 to $100 \%)$. Different environment influenced the shelf-life of bogues (17 d for $\mathrm{BF}$ and $12 \mathrm{~d}$ for $\mathrm{BW}$ ). The results for both the BF and BW samples confirmed the importance of validation of QIM scheme, either through the storage experiment at another location, season, or catching ground. 
The knowledge of shelf-life limiting factors of different fishes species from different the aquatic environments and under different packaging conditions is still limited, hence, studies are needed to optimize the packaging technique and to assess the quality of the fishes during the storage. Specific QIM schemes for variable combinations of fishes species aquatic environment (related to specific microbial contamination) packaging technology need to be developed (Campus et al. 2011).

\section{FUTURE TRENDS}

Thus, it is evident that there is strong need for further studies to provide the European fish sector with multilingual tool for all the important fishes species (Martinsdóttir et al. 2003). The QIM has not been developed for all the commercially important fish species in Europe. Studies are also needed to evaluate the effects of different environmental factors (i.e., packaging, processing, and transport) on the sensory properties and consequently, on the applicability of the QIM. The knowledge of these influences could open up the opportunities for greater control of sensory quality and differentiation of the products. This would also stimulate improvements in the production of seafood of enhanced quality to meet consumers' preferences (Hyldig et al. 2007). Adoption of QIM in the EU and other countries would greatly aid in standardizing the trade in fish and fishes products worldwide (Green 2011). In Brazil, for example, there are some studies developing the QIM scheme for important commercial species such as Piaractus mesopotamicus, Colossoma macropomum, Colossoma macropomum $(F) x$ Piaractus mesopotamicus (M) (Borges et al.), Lophius gastrophysus (Bernardi et al.) and Priacanthus arenatus (Amaral et al.) (unpliblished data).

It is foreseen that the QIM will be useful to give the feedback to the fishermen concerning the quality of their catch, which may influence better handling on-board. A so-called 'catch-index' containing the QIM points may contribute to quality assurance in the whole chain. Fish processing plants would also like to control the freshness stage of their raw material. The QIMevaluation of raw material kept on ice could provide accurate and precise information concerning the freshness and a prediction of the freshness of fillets later to be inspected by the buyers. Sensory evaluation might also contribute to a 'processing index' (Nielsen et al. 2002; Hyldig and Nielsen 2004). Given the usefulness of this method, it is expected that the QIM will become the leading reference method for the assessment of fresh fishes in Europe in the future (Hylgig and Green-Petersen 2004).

The QIM schemes have been developed from the viewpoint of the industry and technical studies, but there have also been studies on developing a version for the consumer QIM (C-QIM) (Warm 2000). C-QIM is developed with the use of an external panel testing their own vocabulary in comparison with the QIM terms of experts. In this scheme, only the intrinsic quality parameters are considered such as the appearance, odor and texture (Hyldig and Nielsen 2004). C-QIM is a tool for decision making for the consumer buying the fish in a market, or at the fishmonger (Nielsen et al. 2002) and its introduction may help the consumer to get a good sensory quality product and learn more about the quality and its variation (Hyldig et al. 2007). Further work in this area is ongoing as new tools are being investigated for the delivery of the QIM with new species and wider use by the industry and consumer groups (Green 2011). According to Nielsen et al. (2002), further attempt to combine the QIM for the raw fishes, profiling for the cooked fillet and C-QIM might, therefore, prove to be a successful in 'translating' the values for sensory quality through the chain.

Fish trade via e-commerce is growing and information on the freshness and quality of the fishes traded unseen must be as inevitable as information on the price given (Martinsdóttir et al. 2003). Objective and standardized sensory methods would make information on fish quality more reliable and readily accessible and would facilitate and enhance the quality and process management in the fish industry. Moreover, a standardized sensory method would facilitate the communication between the buyers and sellers of the fishes and fulfill the demands of inspection authorities and regulations for tracking and tracing the information about the quality of the fishes. It would minimize the cost and effort if the buyers and sellers used the same method (Martinsdóttir 2002).

The unique negative point found in the literature about the QIM would be a challenge for the future studies. Although QIM concept could be applied in many part of the chain from catch to consumer, 
Nielsen et al. (2002) pointed its limitation that only the intrinsic quality cues were considered in the QIM (or other descriptive and discriminative sensory methods). Thus, there was need of a more global approach that also involves the extrinsic quality cues, and suggested the creation of a Total Food Model for the fish, which should contain both objective and subjective quality cues. The model should not only consider the consumer perspective but should also include the perceived quality in the different parts of the chain. In this way it would be possible to recommend the appropriate sensor method for quality measurement in a specific link of the chain.

\section{CONCLUSIONS}

Considering the increase in the demand for information about the quality and freshness by the consumers and growth of e-commerce, QIM appears to be an easy, rapid and efficient tool to assess the storage history and estimate the remaining shelf-life of the fish. The implementation of this standardized method for all the key stages of fishes chain for evaluating the quality freshness of the fishes would help the industry supply safe, high-quality and healthpromoting fish-products, giving a unique value to it. The cooperation between the research institutes and industry would be considered essential for QIM promotion and optimization, developing new schemes for different handling, storage and packaging conditions.

\section{REFERENCES}

Alasalvar C, Grigor JM, Ali Z. Practical evaluation of fish quality by objective, subjective, and statistical testing. In: Alasalvar C, Shahidi F, Miyashita K, Wanasundara U, editors. Handbook of seafood quality, safety and health applications. New Delhi: Blackwell Publishing Ltd; 2011. p.13-29.

Alasalvar C, Taylor KDA, Öksüz A, Garthwaite T, Alexis, MN, Grigorakis K. Freshness assessment of cultured sea bream (Sparus aurata) by chemical, physical and sensory methods. Food Chem. 2001; 72: 33-40.

Alasalvar C, Taylor KDA, Öksüz A, Shahidi F, Alexis M. Comparison of freshness quality of cultured and wild sea bass (Dicentrarchus labrax). J Food Sci. 2002; 67: 3220-3226.
Archer M. Sensory assessment score sheets for fish and shellfish - Torry \& QIM. Edinburgh: Seafish; 2010.

Baixas-Nogueras S, Bover-Cid S, Veciana-Nogués T, Nunes ML, Vidal-Carou MC. Development of a Quality Index Method to evaluate freshness in mediterranean hake (Merluccius merluccius). J Food Sci. 2003; 68(3): 1067-1071.

Barbosa A, Vaz-Pires P. Quality Index Method (QIM): development of a sensorial scheme for common octopus (Octopus vulgaris). Food Control. 2004; 15: 161-168.

Bekaert K. Development of Quality Index Method scheme to evaluate freshness of tub gurnard (Chelidonichthys lucernus). In: Luten JB, Jacobsen C, Bekaert K, Sæbo A, Oehlenschlager J, editors. Seafood research from fish to dish. Wageningen: Wageningen Academic Publishers; 2006. p. 289-296.

Bogdanovic T, Simat V, Frka-Roic A, Markovic K. Development and application of Quality Index Method scheme in a shelf life study of wild and fish farm affected bogue (Boops boops, L.). J Food Sci. 2012; 0: 51-58.

Bonilla AC, Sveinsdottir K, Martinsdottir E. Development of Quality Index Method (QIM) scheme for fresh cod (Gadus morhua) fillets and application in shelf life study. Food Control. 2007; 18(4): 352-358.

Campus M, Bonaglini E, Cappuccinelli R, Porcu MC, Tonelli R, Roggio T. Effect of modified atmosphere packaging on Quality Index Method (QIM) scores of farmed gilthead seabream (Sparus aurata L.) at low and abused temperatures. J Food Sci. 2011; 76(3): 185-191.

Chebet L. "Rapid" (alternative) methods for evaluation of fish freshness and quality [Msc Thesis]. Akureyri, Iceland: University of Akureyri; 2010.

Cyprian OO, Sveinsdóttir K, Magnússon $\mathrm{H}$, Martinsdóttir E. Application of Quality Index Method (QIM) scheme and effects of short-time temperature abuse in shelf life study of fresh water artic char (Salvelinus alpinus). J Food Prod. Technol. 2008; 17: 303-321.

Esteves E, Aníbal J. Quality Index Method (QIM): utilização da análise sensorial para determinação da qualidade do pescado. In: XIII Congresso do Algarve: Actas Proceedings; 2007 Nov; Racal-Clube, Lagos, Portugal. Lagos: Racal-Clube; 2007. p. 365373.

Gonçalves AC. Qualidade e valorização em aquacultura: Propriedades sensoriais e período de conservação útil de peixe e bivalves [Doc Thesis]. Lisboa, Portugal: Universidade de Lisboa; 2010.

Green DP. Sensory evaluation of fish freshness and eating qualities. In: Alasalvar C, Shahidi F, Miyashita $\mathrm{K}$, Wanasundara U, editors. Handbook of seafood quality, safety and health applications. New Delhi: Blackwell Publishing Ltd; 2011. p. 29-38. 
Green-Petersen DMB. Sensory quality of seafood - in the chain from catch to consumption [PhD Thesis]. Copenhagen, Denmark: University of Denmark; 2010.

Guillerm-Regost C, Haugen T, Nortvedt R, Carlehög M, Lunestad BT, Kiessling A, et al. Quality characterization of farmed atlantic halibut during ice storage. J Food Sci. 2006; 71(2): 83-90.

Herrero AM, Huidobro A, Careche M. Development of a Quality Index Method for frozen hake (M. Capensis and M. Paradoxus). J Food Sci. 2003; 68(3): 10861092.

Howgate P. Traditional methods. In: Rehbein H, Oehlenschläger J, editors. Fishery products: quality, safety and authenticity. Oxford: Blackwell Publishing Ltd, 2009. p.19-41.

Huidobro A, Pastor A, Tejada M. Quality index method developed for raw gilthead seabream (Sparus aurata). J Food Sci. 2000; 65: 1202-1205.

Huidobro A, Pastor A, López-Caballero ME, Tejada M. Washing effect on the Quality Index Method (QIM) developed for raw gilthead seabream (Sparus aurata). Eur Food Res Techno. 2001; 212(4): 408-412.

Hyldig G, Bremner A, Martinsdóttir E, Schelvis R. Quality Index Methods. In: Nollet LML, Boylston T, Chen F, editors. Handbook of meat, poultry and seafood quality. Oxford: Blackwell, 2007. p. 499510.

Hyldig G, Green-Petersen, DMB. Quality Index Method - an objective tool for determination of sensory quality. J Aquat Food Prod. Technol. 2004; 13(4): 71-80.

Hyldig G, Martinsdóttir E, Sveinsdóttir K, Schelvis R, Bremner A. Quality Index Methods. In: Nollet LML, Toldrá F, editors. Handbook of seafood and seafood products analysis. New Jersey: CRC Press; 2010. p. 463-481.

Hyldig G, Nielsen J. QIM - a tool for determination of fish freshness. In: Shahidi F, Simpson BK, editors. Seafood quality and safety- advances in the new millennium. St John's: Science Tech. Publishing Company; 2004. p. 81-89.

Lyhs U, Schelvis-Smit R. Development of a Quality Index Method (QIM) for maatjes herring stored in air and under modified atmosphere. J Aquat Food Prod Technol. 2005; 14: 63-76.

Martinsdóttir E, Sveinsdottir K, Luten JB, SchelvisSmit R, Hyldig G. Reference manual for the fish sector: sensory evaluation of fish freshness. Ijmuiden: QIM Eurofish; 2001.

Martinsdóttir E. Quality management of stored fish. In: Bremner A, editor. Safety and quality issues in fish processing. Hirtshals: Woodhead Publishing Ltd.; 2002. p. 360-378.
Martinsdóttir E, Luten JB, Schelvis-Smit AAM, Hyldig G. Developments of QIM - past and future. In: Luten $\mathrm{JB}$, Oehlenschlåger J, Ólafsdóttir $\mathrm{G}$, editors. Quality of fish from catch to consumer. Netherlands: Wageningen Academic Publishers; 2003. p. 265-272.

Massa AE, Palacios DL, Paredi ME, Crupkin M. Postmortem changes in quality indices of ice-stored flounder (Paralichtys patagonicus). J Food Biochem. 2005; 29: 570-590.

Musgrove R, Carragher J, Mathews, Slattery S. Valueadding australian sardines: factors affecting rates of deterioration in sardine (Sardinops sagax) quality during post-harvest handling. Food Control. 2007; 18:1372-1382.

Nielsen D. Quality Index Method provides objective seafood assessment. Glob Aquacutl Advoc. 2005; 3638.

Nielsen D, Green D. Developing a quality index grading tool for hybrid striped bass (Morone saxatilis $x$ Morone chrysops) based on the Quality Index Method:. Int J Food Sci Tech. 2007; 42(1): 86-94.

Nielsen D, Hyldig G. Influence of handling procedures and biological factors on the QIM evaluation of whole herring (Clupea harengus L.) Food Res Int. 2004; 37(10): 975-983.

Nielsen D, Hyldig G, Larsen E. Eating quality of fish a review. J Aquat Food Prod Technol. 2002; 11: 125149.

Noojuy N, Boonprab K. Quality Index Method (QIM) and its related indexes for meder's mangrove crab (Neoepisesarma Mederi, H. Milne Edwards 1853) stored in ice. Kmitl Sci J. 2008; 8(2): 52-59.

Nunes ML, Batista I, Cardoso C. Aplicação do índice de qualidade (QIM) na avaliação da frescura do pescado. Lisboa: Publicações Avulsas do IPIMAR; 2007.

Ólafsdóttir G, Martinsdóttir E, Oehlenschläger J, Dalgaard P, Jensen B, Undeland I, et al. Methods to evaluate fish freshness in research and industry. Trends F Sci Technol. 1997; 8: 258-265.

Oliveira VM, Freitas MQ, Clemente SCS, Mársico ET. Método do Índice de Qualidade (MIQ) desenvolvido para camarão (Litopeneaus vannamei) cultivado. Rev. Univ. Rur. Série Ciências da Vida. 2009; 29: 60-71.

Özogul Y, Özyurt G, Özogul F, Kuley E, Polat A. Freshness assessment of european eel (Anguilla anguilla) by sensory, chemical and microbiological methods. Food Chem. 2005; 92: 745-751.

Özyurt G, Kuley E, Özkütük S, Özogul F. Sensory, microbiological and chemical assessment of the freshness of red mullet (Mullus barbatus) and goldband goatfish (Upeneus moluccensis) during storage in ice. Food Chem. 2009; 114: 505-510. 
Pons-Sánchez-Cascado S, Vidal-Carou MC, Nunes ML, Veciana-Nogués MT. Sensory analysis to assess the freshness of mediterranean anchovies (Engraulis encrasicholus) stored in ice. Food Control. 2006; 17: 564-569.

Portela CDG. Tecnologia pós-despesca dos camarões de água doce Macrobrachium rosenbergii e Macrobrachium amazonicum [Doc Thesis]. Jaboticabal, Brazil: Universidade Estadual Paulista; 2009.

Rodrigues TP. Estudo de critérios para avaliação da qualidade da tilápia do Nilo (Oreochromis niloticus) cultivada; eviscerada e estocada em gelo [Msc Thesis]. Niterói, Brazil: Universidade Federal Fluminense; 2008.

Sant'ana LS, Soares SM, Vaz-Pires P. Development of a Quality Index Method (QIM) sensory scheme and study of shelf-life of ice-stored blackspot seabream (Pagellus bogaraveo). LW T/Food Sci Tech. 2011; 44: 2253-2259.

Sen DP. Advances in fish processing technology. New Delhi: Allied Publishers Pvt Ltd; 2005.

Silva KB. Avaliação do frescor e vida útil da lagosta (Panulirus argus), pré- cozida e armazenada sob refrigeração [Msc Thesis]. Recife, Brazil: Universidade Federal Rural do Semi-Árido; 2009.

Silva SC. Validade comercial de sardinhas inteiras e refrigeradas avaliadas por análises físico-químicas, bacteriológicas e sensorial. Niterói, Brazil: Universidade Federal Fluminense; 2010.

Song Y, Liu L, Shen H, You J, Luo Y. Effect of sodium alginate-based edible coating containing different anti-oxidants on quality and shelf life of refrigerated bream (Megalobrama amblycephala). Food Control. 2011; 22: 608-615.

Sveinsdóttir K, Martinsdóttir E, Hyldig G, Jørgensen B, Kristbergsson K. Application of Quality Index Method (QIM) scheme in shelf-life study of farmed atlantic salmon (Salmo salar). J Food Sci. 2002; 67(4): 1570-1579.
Sveinsdóttir K, Hyldig G, Martinsdottir E, Jørgensen B, Kristbergsson K. Quality Index Method (QIM) scheme developed for farmed atlantic salmon (Salmo salar). Food Qual Pref. 2003; 14: 237-245.

Sykes AV, Oliveira AR, Domingues PM, Cardoso CM, Andrade JP, Nunes ML. Assessment of european cuttlefish (Sepia officinalis, L.) nutritional value and freshness under ice storage using a developed Quality Index Method (QIM) and biochemical methods. LWT/ Food Sci Tech. 2009; 42:424-432.

Teixeira MS, Borges A, Franco RM, Clemente, SCS, Freitas, MQ. Método de Índice de Quaidade (MIQ): protocolo sensorial para corvina (Micropogonias furnieri). Rev Bras Ciênc Vet. 2009; 16: 83-88.

Triqui R, Bouchriti N. Freshness assessments of maroccan sardine (Sardina pilchardus) comparison of overall sensory changes to instrumentally determined volatiles. J Agr Food Chem. 2003; 51: 7540-7546.

Vaz-Pires P, Seixas P. Development of new Quality Index Method (QIM) schemes for cuttlefish (Sepia officinalis) and broadtail shortfin squid (Illex coindetii). Food Control. 2006; 17(12): 942-949.

Warm K, Nielsen J, Hylgig G, Martens M. Sensory quality of five fish species. J Food Qual. 2000; 23(6): 583-602.

Wünnenburg A, Oehlenschläger J. Untersuchungen zur saisonalen Abhängigkeit der Haltbarkeit von Zuchtforellen (Onchorhynchus mykiss) während der Eislagerung mittels der Qualitäts-Index-Method (QIM) an Ganzfisch und Sensorik gegarter Filetproben. Archiv für Lebensmittelhyg. 2008; 59: 221-226. 